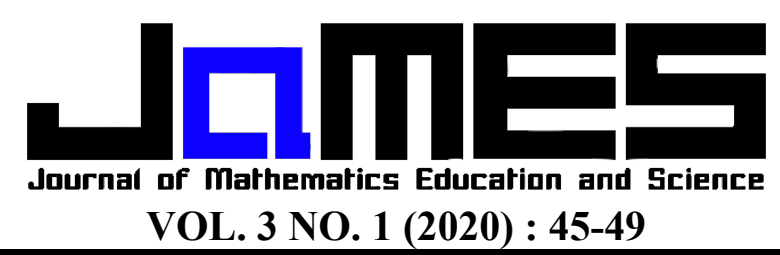

p-ISSN: 2621-1203

https://doi.org/10.32665/james.v3i1.135

e-ISSN: 2621-1211

\title{
KEMAMPUAN PEMECAHAN MASALAH MATEMATIS MAHASISWA PENDIDIKAN MATEMATIKA UNIVERSITAS NAHDLATUL ULAMA SUNAN GIRI BOJONEGORO
}

\author{
Nurul Ilmiyah", Anisa Fitri² \\ Universitas Nahdlatul Ulama Sunan Giri, nurulilmiyah@unugiri.ac.id ${ }^{1}$ \\ Universitas Nahdlatul Ulama Sunan Giri, anisafitri@unugiri.ac.id ${ }^{2}$ \\ Received : 29 April 2020, Revised : 30 April 2020, Accepted : 30 April 2020 \\ (C) Mathematics Education Unugiri 2020
}

\begin{abstract}
This study aims to describe the mathematical problem solving ability of students at the University of Nahdlatul Ulama Sunan Giri Bojonegoro. This study is a qualitative study with research subjects of the Nahdlatul Ulama University Mathematics Education Study Program Sunan Giri Bojonegoro odd semester 2019 - 2020, namely semester 1 students of class 2019. Determination of research subjects using purposive sampling. Data collection techniques using written tests and interviews. Data analysis techniques used include data collection, data reduction, data presentation and verification. The validity of the data used in this study uses time triangulation that compares written data and interviews. The results showed that students 'mathematical problem solving abilities were still low, it was seen from the percentage of students' problem solving abilities where students who were unable to solve problems still occupied the highest presentations and students who were able to solve problems very well occupied the lowest percentage.
\end{abstract}

Keywords: Matehematical Problem Solving

\begin{abstract}
Abstrak
Penelitian ini bertujuan untuk mendeskripsikan kemampuan pemecahan masalah matematis mahasiswa Universitas Nahdlatul Ulama Sunan Giri Bojonegoro. Penelitian ini merupakan penelitian kualitatif dengan subjek penelitian mahasiswa Program Studi Pendidikan Matematika Univesitas Nahdlatul Ulama Sunan Giri Bojonegoro semester ganjil tahun akademik 2019 - 2020, yaitu mahasiswa semester 1 angkatan 2019. Penentuan subjek penelitian menggunakan purposive sampling. Teknik pengumpulan data menggunakan tes tertulis dan wawancara. Teknik analisis data yang digunakan meliputi pengumpulan data, reduksi data, penyajian data dan verifikasi. Validitas data yang digunakan dalam penelitian ini menggunakan triangulasi waktu yang membandingkan antara data tertulis dan wawancara. Hasil penelitian menunjukkan bahwa kemampuan pemecahan masalah matematis mahasiswa masih rendah, hal tersebut terlihat dari presentase kemampuan pemecahan masalah mahasiswa dimana mahasiswa yang tidak mampu memecahkan masalah masih menduduki presentasi tertinggi dan mahasiswa yang mampu memecahkan masalah dengna sangat baik menduduki presentase paling rendah.
\end{abstract}

\section{Kata kunci: Pemecahan masalah matematika}

\section{Pendahuluan}

Suatu pertanyaan atau soal dalam matematika merupakan suatu masalah apabila pertanyaan atau soal tersebut menantang untuk diselesaikan atau dijawab, dan prosedur untuk menyelesaikannya tidak dapat dilakukan secara rutin. Suatu situasi tertentu dapat merupakan masalah bagi orang tertentu, tetapi belum tentu merupakan masalah bagi seseorang pada waktu tertentu, akan tetapi belum tentu merupakan masalah baginya pada saat yang berbeda [1]. Seorang akan menganggap suatu pertanyaan 
menjadi masalah apabila mengalami kesulitan dalam mencari solusi dari soal atau pertanyaan dengan menggunakan pengetahuan yang dimilikinya. Seseorang akan mampu menyelesaikan suatu masalah, jika seseorang tersebut benar-benar memahami prinsip-prinsip yang telah dipelajari sebelumnya. Seseorang memerlukan prasyarat pengetahuan, ketrampilan, dan pemahaman untuk menyelesaikan masalah.

$A$ problem is a situation that has no immediate solution or known solution strategy [2]. Pendapat yang sama mengungkapkan bahwa masalah terjadi karena adanya kesenjangan situasi saat ini dengan situasi mendatang, atau keadaan saat ini dengan tujuan yang diinginkan [3].

Memecahkan masalah matematika merupakan suatu proses mental yang kompleks dan memerlukan visualisasi, imajinasi, manipulasi, analisis, abstraksi, maupun penyatuan ide [4]. Pemecahan masalah matematika tidak terlepas dari pengetahuan seseorang akan substansi masalah tersebut. Misalnya bagaimana memahami dari inti masalah tersebut, prosedur/langkah apa yang digunakan dalam memecahkan masalah tersebut.

Pemecahan masalah matematika dipandang sebagai proses dan tujuan dari pembelajaran matematika, sebagai proses sebagai teknik dan pendekatan sedangkan sebagai tujuan berarti sebagai kemampuan kognitif yang dicapai setelah proses pembelajaran. Belajar pemecahan masalah pada dasarnya adalah belajar menggunakan metode-metode ilmiah atau berpikir secara sistematis, logis, teratur dan teliti. Tujuannnya adalah untuk memperoleh kemampuan dan kecakapan kognitif untuk memecahkan masalah secara rasional, lugas dan tuntas [5].

Kemampuan dalam memecahkan masalah harus dimiliki oleh mahasiswa, lebih khusus mahasiswa S1 Program Studi Pendidikan Matematika Universitas Nahdlatul Ulama Sunan Giri Bojonegoro (Unugiri) sebagai mahasiswa yang dipersiapkan untuk menjadi calon guru matematika kedepannya. Hal ini Berkaitan dengan tujuan diberikannya pembelajaran matematika ditingkat sekolah menengah yaitu agar peserta didik memiliki kemampuan pemecahan masalah. Untuk dapat memiliki kemampuan tersebut, mahasiswa dituntut mengikuti pola belajar matematika di perguruan tinggi. Pembelajaran matematika di kelas harus melibatkan aktivitas yang mendukung semua mahasiswa untuk meningkatkan dan mengembangkan keterampilan pemecahan masalah, komunikasi serta mencapai kebiasaan berpikir matematis.

Pemecahan masalah memiliki manfaat, yaitu: (1) mengembangkan ketrampilan kognitif secara umum, (2) mendorong kreativitas, (3) pemecahan masalah merupakan bagian dari proses aplikasi matematika, dan (4) memotivasi siswa untuk belajar matematika [6].

Belajar matematika di tingkat perguruan tinggi umumnya melibatkan kemampuan kognitif tingkat tinggi, seperti kemampuan analisis, sintesis, dan evaluasi, bukan sekedar mengingat kemampuan faktual ataupun aplikasi sederhana dari berbagai formula atau prinsip [7]. Belajar dan berpikir matematika di tingkat perguruan tinggi mengharuskan mahasiswa memiliki kemampuan untuk mengeksplorasi dan memberikan alasan logis dalam memecahkan masalah non-rutin serta menghubungkan ide-ide dan aturan dalam matematika, antara matematika, dan aktivitas intelektual lainnya. Salah satu daya matematis yang sangat penting harus dimiliki mahasiswa adalah kemampuan pemecahan masalah. Terdapat empat langkah dalam pemecahan masalah, yaitu understanding the problem (memahami masalah), devising a plan (merencanakan penyelesaian), carrying out the plan (melaksanakan penyelesaian), dan looking back (memeriksa kembali) [8]. Mengajarkan bagaimana menyelesaikan masalah merupakan kegiatan guru untuk memberikan tantangan atau motivasi kepada para siswa agar mereka mampu memahami masalah tersebut, tertarik untuk memecahkannya, mampu menggunakan semua pengetahuannya untuk merumuskan strategi dalam memecahkan masalah tersebut, melaksanakan strategi dan menilai apakah jawabannya benar.

Salah satu mata kuliah yang ditempuh mahasiswa program studi pendidikan matematika adalah kalkulus 1. Mata kuliah ini merupakan prasyarat sebelum menempuh mata kuliah berikutnya, yaitu kalkulus 2, kalkulus lanjut, persamaan diferensial biasa, dll. Melihat pentingnya mata kuliah kalkulus 1, mahasiswa dituntut untuk menguasai setiap materi yang ada di dalamnya.

Berdasarkan uraian di atas, peneliti bermaksud untuk melakukan analisis terhadap kemampuan pemecahan masalah matematis mahasiswa S1 program studi pendidikan matematika Universitas Nahdlatul Ulama Sunan Giri Bojonegoro pada mata kuliah Kalkulus 1. 


\section{Metode Penelitian}

Penelitian ini merupakan penelitian kualitatif. Bogdan dan Taylor [9] mendefinisikan penelitian kualitatif sebagai prosedur penelitian yang menghasilkan data deskriptif berupa kata-kata tertulis atau lisan dari orang-orang dan perilaku yang diamati. Dalam penelitian ini, peneliti akan mendeskripsikan kemampuan pemecahan masalah matematis mahasiswa S1 program studi pendidikan matematika Universitas Nahdlatul Ulama Sunan Giri pada mata kuliah Kalkulus 1 berdasarkan hasil Tes Kemampuan Pemecahan Masalah Matematis (TKPM).

Objek penelitian ini adalah kemampuan pemecahan masalah matematis mahasiswa pada Mata Kuliah Kalkulus 1. Sedangkan subjek penelitian ini adalah mahasiswa Program Studi Pendidikan Matematika Univesitas Nahdlatul Ulama Sunan Giri Bojonegoro semester ganjil tahun akademik 2019 - 2020, yaitu mahasiswa semester 1 angkatan 2019. Lokasi penelitian dalam penelitian ini adalah ruang kelas Program Studi Pendidikan Matematika Univesitas Nahdlatul Ulama Sunan Giri Bojonegoro.

Rancangan penelitian yang digunakan pada penelitian ini adalah "One Shot Case Study" yaitu suatu kelas yang terpilih diberikan tes kemampuan pemecahan masalah matematis. Setelah itu dilakukan pendeskripsian terhadap kemampuan pemecahan masalah matematis mahasiswa.

Teknik pengumpulan data yang digunakan dalam penelitian ini adalah teknik pengukuran dan komunikasi langsung melalui wawacara. Teknik pengukuran yang dimaksud yaitu melalui pemberian tes kepada mahasiswa yang berisi materi limit dan kekontinuan dengan berorientasi pada kemampuan pemecahan masalah matematis. Sedangkan wawancara adalah teknik yang digunakan untuk memperoleh data pelengkap dari hasil tes.

Tes Kemampuan Pemecahan masalah Matematika disusun berdasarkan karakteristik pemecahan masalah menurut Polya, yaitu understanding the problem (memahami masalah), devising a plan (merencanakan penyelesaian), carrying out the plan (melaksanakan penyelesaian), dan looking back (memeriksa kembali). Melalui tes ini diharapkan mahasiswa memiliki kemampuan dalam memahami masalah, merencanakan penyelesaian masalah, melaksanakan penyelesaian masalah, dan memeriksa kembali penyelesaian masalahnya.
Soal tes yang disusun terdiri dari 3 butir soal. Ketiga soal tersebut merupakan adopsi buku kalkulus karya Edwin J. Purcell dan Dale Varberg. Soal tes yang telah dibuat akan divalisasi oleh validator, kemudian direvisi sesuai dengan penilaian dan saran dari validator.

Validasi dilakukan oleh ahli. Validasi berupa pertimbangan dan saran ahli terhadap soal Tes Kemampuan Pemecahan matematika untuk mata kuliah kalkulus I digunakan sebagai dasar untuk melakukan revisi.

Kemampuan pemecahan masalah matematis mahasiswa program studi Pendidikan matematika Universitas Nahdlatul Ulama Sunan Giri pada mata kuliah Kalkulus I dengan sub materi Limit dan Kekontinuan diberikan pada tanggal 16 Oktober 2019. Tes ini diikuti oleh 49 mahasiswa semester 1 yang terdiri dari 45 mahasiswa perempuan dan 4 mahasiswa laki-laki.

Berdasarkan hasil tes kemampuan pemecahan masalah, maka diperoleh diagram kemampuan pemecahan masalah matematis mahasiswa semester 1 program studi Pendidikan matematika UNUGIRI sebagai berikut:

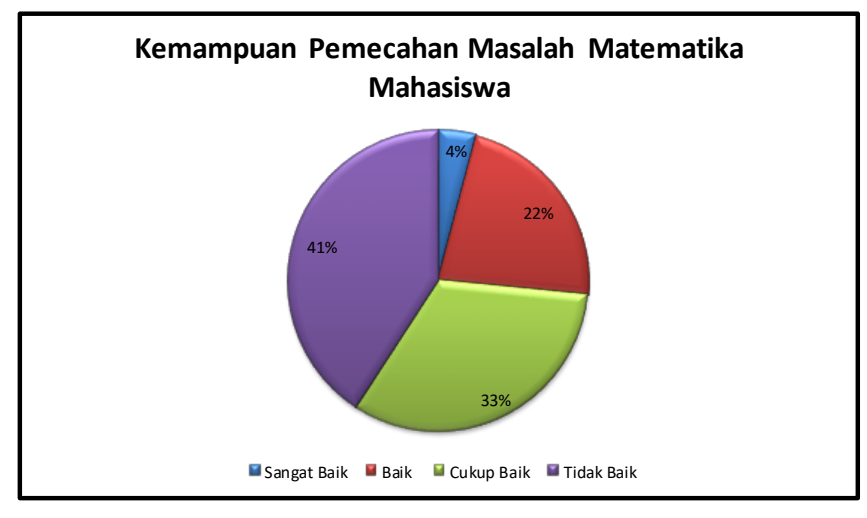

Diagram 1. Hasil Kemampuan Pemecahan Maalah Matematis Mahasiswa

Berdasarkan diagram di atas, dapat diketahui bahwa sebanyak 20 mahasiswa (41\%) memenuhi kriteria tidak baik dalam memecahkan masalah, 16 mahasiswa (33\%) memenuhi kriteria cukup baik dalam memecahkan masalah, 11 mahasiswa (22\%) memenuhi kriteria baik dalam memecahkan masalah, dan 2 mahasiswa (4\%) memenuhi kriteria sangat baik dalam memecahkan masalah.

Hasil diatas menunjukkan bahwa hanya 13 mahasiswa (26\%) yang memenuhi kriteria baik atau sangat baik dalam memecahkan masalah. Sehingga dapat dikatakan bahwa kemampuan pemecahan masalah matematis mahaiswa semester 1 program studi Pendidikan matematika Universitas Nahdlatul Ulama Sunan Giri 
Bojonegoro termasuk dalam kategori tidak baik dalam memecahkan masalah, artinya mahasiswa belum mampu dalam memahami masalah, merencanakan penyelesaian, melaksanakan penyelesaian, dan memeriksa kembali penyelesaian.

Berikut ini akan disajikan deskripsi hasik kemampuan pemecahan masalah matematis mahasiswa berdasarkan hasil wawancara:

1. Mahasiswa dengan kategori sangat baik dalam memecahkan masalah

Pada kategori ini mahasiswa mampu menunjukkan pemahaman terhadap soal dengan mengubah kalimat pada soal menjadi model matematika dan menggunakan konsep lain untuk menentukan Panjang tiap rusuk pada bujursangkar. Hal ini juga dipertegas pada saat wawancara, mahasiswa mampu menjelaskan dengan baik maksud soal dan bagaimana langkah penyelesaiannya. Mahasiswa tersebut juga menunjukkan pemahaman yang baik terhadap konsep limit.

2. Mahasiswa dengan kategori baik dalam memecahkan masalah

Mahasiswa pada kategori ini mampu memahami masalah dengan mengungkapkan apa yang diketahui dalam soal, selanjutnya mampu menjelaskan bagaimana langkah dalam menyelesaikan masalah tersebut, namun mahasiswa tersebut belum membuat generalisasi untuk jawaban tersbut, bahwa agar fungsi kontinu disetiap titik, maka harus ditunjukkan terlebih dahulu bahwa fungsi kontinu di sembarang konstanta $c$.

3. Mahasiswa dengan kategori cukup baik dalam memecahkan masalah

Mahasiswa kategori ini mampu mengutarakan apa yang dimaksudkan dalam soal, namun mahasiswa tersebut belum mampu dalam merencanakan penyelesaian. Hal ini ditunjukkan bahwa mahasiswa kurang baik dalam membuat fungsi $f$ dan $g$. dalam soal diketahui bahwa $f(x) \cdot g(x)=1$, kemudian mahasiswa menuliskan bahwa $f(x)=\frac{1}{g(x)}$. Padahal dalam menyelesaikan permasalahan ini, memerlukan kreativitas mahasiswa untuk memisalkan fungsi $f$ dan $g$, misalkan $f(x)=\frac{1}{x}$ dan $g(x)=x$, dan $c=0$. Hal ini diperlukan agar dapat menunjukkan bahwa $\lim _{x \rightarrow a} f(x)$ tidak ada.

4. Mahasiswa dengan kategori tidak baik dalam memecahkan masalah

Mahasiswa yang termasuk dalam kategori tidak baik dalam memecahkan masalah dapat diartikan bahwa mahasiswa tersebut tidak mampu dalam memahami masalah, merencanakan penyelesaian, melaksanakan penyelesaian, dan memeriksa kembali penyelesaian. Mahasiswa tidak mampu memahami masalah. Dalam soal tertulis "bujursangkar $\mathrm{R}$ bersinggungan dengan titik tengah sisi-sisi dari suatu segiempat $\mathrm{Q}$ dengan titik-titik $( \pm x, 0)$ dan $(0, \pm 1)$ ". Pemahaman dalam soal tersebut bahwa segiempat berada didalam bujursangkar, namun mahasiswa melakukan hal sebaliknya, bahwa model yang dibuat adalah segiempat berada di luar segiempat. Hal ini mengakibatkan pelaksanaan penyelesaian tidak menunjukkan jawaban ynag benar.

\section{Penutup}

Berdasarkan penelitian ini dapat disimpulkan bahwa rata-rata kemampuan pemecahan masalah matematis mahasiswa masih rendah, hal tersebut terlihat dari presentase kemampuan pemecahan masalah mahasiswa dimana mahasiswa yang tidak mampu memecahkan masalah masih menduduki presentasi tertinggi dan mahasiswa yang mampu memecahkan masalah dengna sangat baik menduduki presentase paling rendah.

Selanjutnya peneliti memberikan saran bahwa Soal HOTS untuk matematika sekolah menengah atas pada penelitian ini sudah memenuhi kriteris valid dan siap digunakan untuk ujicoba terbatas untuk selanjutnya dianalisis dan direvisi untuk mendapatkan prototipe final yang digunakan untuk implementasi.

Untuk mendorong peningkatan kemampuan berpikir tingkat tinggi siswa perlu dilatihkan kepada 
siswa untuk mengerjakan soal-soal yang sesuai dengan higher order thinking skills.

\section{Referensi}

[1] Hamzah, Upu. 2003. Problem Posting dan Problem Solving dalam Pembelajaran Matematika. Jakarta: Pustaka Ramadhan.

[2] Kennedy, L. M., Tipps, S., dan Johnson, A. 2008. Guilding Learning of Mathematics. Belmont: Thomson Wadsworth.

[3] Suharman . 2005. Psikologi Kognitif. Surabaya: Srikandi

[4] Sumuslistiana.2011. Profil Metakognisi Siswa Kelas VII SMP Mardi Sunu Surabaya Dalam Pemecahan Masalah Matematika Ditinjau Dari Perbedaan Kemampuan Matematika. Surabaya: Tesis UNESA.

[5] Syah, M. 2008. Psikologi Pendidikan dengan Pendekatan Baru. Bandung: PT Remaja Rosdakarya.
[6] Pehkonen, E. 1997. The State-of-Art in Mathematical Creativity. Zentralbalt fur Didaktic der Mathematic (ZDM) - The International Journal on Matematics Education, 29(3) : 63-67. ISSN: 1615-69X.

[7] Fadhila, S. \& Jamilah. 2014. Pengembangan Bahan Ajar Struktur Aljabar untuk Meningkatkan Kemampuan Pembuktian Matematis Mahasiswa. Jurnal Ilmiah Pendidikan. Cakrawala Pendidikan. Februari 201, Th XXXV No.1.

[8] Polya, G. 1957. How to Solve It, A New Aspect Of Mathematical Method. New Jersey: Princeton University Press.

[9] Moleong, Lexy. 2000. Metodologi Penelitian Kualitatif. Bandung: Rosdakarya 